\title{
FATF Recommendations Related to DNFBPs on Anti Money Laundering Assessment
}

\author{
Normah Omar and Haslinn Hajudin
}

\begin{abstract}
Globally, member countries are expected to comply to the international standard on anti-money laundering and anti-financing of terrorism proposed by the Financial Action Task Force (FATF) money laundering activities are monitored through the the stipulated recommendations The paper analyzed the compliance rate among five chosen countries (Canada, France, Spain, Mexico and Sweden) as related to FATF 40+9 Recommendations especially on Recommendations for Designated Non-Financial Businesses and Professions (DNFBPs). This study also looks at factors underlying the compliance among countries chosen. This analysis will give better understanding on the level of compliance among countries chosen.
\end{abstract}

Index Terms-DNFBPs, AML/CFT, law enforcement.

\section{INTRODUCTION}

The FATF research highlighted a trend in the use of complex commercial arrangements by money launders and terrorism financiers to hide their money trail. These arrangements often use the services of professionals such as lawyers, accountants and company secretaries. Arising from these typologies, the FATF standards require countries to improve their Anti-Money Laundering and Counter Financing of Terrorism (AML/CFT) measures on DNFBPs.

\section{RISKS RELATED TO DNFBPS}

The acronym of the day is 'DNFBP', or Designated Non-Financial Businesses and Professions. It is the FATF catch-all for any business or profession that poses a money laundering risk but cannot be classified as a financial institution.

Thus, the risks related to this sector lie in the potential misuse for ML/TF. Some countries realized these risks and, therefore, adopted measures in an attempt to prevent the misuse of non-financial businesses and professions in ML/TF [1]. They found that these businesses and professions comprise real estate agents, accountants, lawyers, and casinos, dealers in automobiles and boats and horse races.

\section{REAL CASES RELATED TO DNPBPS}

Every year, huge amounts of funds are generated from illegal activities such as drug trafficking, tax evasion, people smuggling, theft, arms trafficking and corrupt practices. These funds are mostly in the form of cash.

The criminal who generate these funds need to bring them

Manuscript received August 23, 2013; revised November 9, 2013.

Normah Omar is with the Accounting Research Institute, Universiti Teknologi MARA, Malaysia (e-mail: normah645@salam.uitm.edu.my). into the legitimate financial system without raising suspicion. The conversion of cash into other forms makes it more useable. It also put a distance between the criminal activities and the funds.

Persons engaged in the laundering of criminal proceeds are relentless in their efforts to contrive new ways of achieving their objectives of making 'dirty money' clean.

\section{A. Case 1}

- Huge cocaine shipment intercepted

A number of unusually large international funds transfer instructions (IFTIs) from Australia to Asia (totaling over AUD3 million during a two-month period) prompted AUSTRAC to forward information about the transfers to law enforcement agencies. Investigating officers found it suspicious that over AUD8 million had been transferred overseas mostly within an 18-month period, when the company had been operating for several years without any prior international funds transfer activity. Further investigations also identified a second suspect who was also transferring money from Australia into to the same accounts in Asia.

The second suspect continued to send money to accounts in Asia through an intermediary acting on his instructions. These instructions were captured on IFTI reports submitted to AUSTRAC. Subsequent investigations identified a shipping container from overseas due to be delivered to the second suspect. When the container arrived in Australia, it was found to be concealing a large, commercial quantity of cocaine. Law enforcement officers arrested several suspects as a result of the investigation.

\section{B. Case 2}

- Student arrested carrying $\$ 88,000$ cash

A Chinese national student was stopped while entering Australia on a flight originating in China. Law enforcement officers found that the student was carrying approximately USD75, 000 (equivalent to about AUD88, 000) of undeclared currency. The student had previously come to the notice of AUSTRAC due to suspicions about a large cash deposit which was possibly also linked to undeclared currency coming into Australia. The student was charged under section 53 of the AML/CTF Act with one count of failing to report movement of more than AUD10,000 in Australian currency into Australia.

(Both case from AUSTRAC Typologies and Case Studies Report 2009)

\section{AML/CFT INTERNATIONAL REQUIREMENTS IN RELATION TO DNFBPS}

The FATF issued four Recommendations, 12, 16, 24 and 
25, on DNFBPs to help countries impose the necessary controls on these businesses. The interpretative notes of these Recommendations include the following general information [2], [3]:

1) Recommendations 5-16, 21 and 22 provide that financial institutions and designated non-financial businesses and professions should take certain actions. These Recommendations require countries to take measures that oblige financial institutions and designated non-financial businesses and professions to comply with each Recommendation. The basic obligations under Recommendations 5, 10 and 13 should be set out in laws or regulations, while more detailed elements in those Recommendations, as well as obligations under other Recommendations, could be required either by laws, regulations, or other enforceable means.

2) To comply with Recommendations 12 and 16, countries do not need to issue laws or regulations that relate exclusively to lawyers, notaries, accountants and the other designated non-financial businesses and professions so long as these businesses or professions are included in laws or regulations covering the underlying activities.

3) The Interpretative Notes that apply to financial institutions are also relevant to designated non-financial businesses and professions, where applicable.

\section{A. Recommendation 12}

The customer due diligence and record-keeping requirements set out in Recommendations 5, 6, and 8 to 11 apply to designated non-financial businesses and professions in the following situations [4]:

- Casinos - when customers engage in financial transactions equal to or above the applicable designated threshold.

- Real estate agents - when they are involved in transactions for their client concerning the buying and selling of real estate.

- Dealers in precious metals and dealers in precious stones - when they engage in any cash transaction with a customer equal to or above the applicable designated threshold.

1) Lawyers, notaries, other independent legal professionals and accountants when they prepare for or carry out transactions for their client concerning the following activities:

- Buying and selling of real estate;

- Managing of client money, securities or other assets;

- Management of bank, savings or securities accounts;

- Organisation of contributions for the creation, operation or management of companies;

- Creation, operation or management of legal persons or arrangements, and buying and selling of business entities.

2) Trust and company service providers when they prepare for or carry out transactions for a client concerning the activities listed in the definition in the Glossary.

\section{B. Recommendation 16}

The requirements set out in Recommendations 13 to 15 , and 21 apply to all designated non-financial businesses and professions, subject to the following qualifications:

1) Lawyers, notaries, other independent legal professionals and accountants should be required to report suspicious transactions when, on behalf of or for a client, they engage in a financial transaction in relation to the activities described in Recommendation 12(d). Countries are strongly encouraged to extend the reporting requirement to the rest of the professional activities of accountants, including auditing.

2) Dealers in precious metals and dealers in precious stones should be required to report suspicious transactions when they engage in any cash transaction with a customer equal to or above the applicable designated threshold.

3) Trust and company service providers should be required to report suspicious transactions for a client when, on behalf of or for a client, they engage in a transaction in relation to the activities referred to Recommendation 12(e).

Lawyers, notaries, other independent legal professionals, and accountants acting as independent legal professionals, are not required to report their suspicions if the relevant information was obtained in circumstances where they are subject to professional secrecy or legal professional privilege $[5]$.

\section{Recommendation 24}

Designated non-financial businesses and professions should be subject to regulatory and supervisory measures as set out below:

1) Casinos should be subject to a comprehensive regulatory and supervisory regime that ensures that they have effectively implemented the necessary AML/CFT measures. At a minimum:

- Casinos should be licensed;

- Competent authorities should take the necessary legal or regulatory measures to prevent criminals or their associates from holding or being the beneficial owner of a significant or controlling interest, holding a management function in, or being an operator of a casino

- Competent authorities should ensure that casinos are effectively supervised for compliance with requirements to AML/CFT.

2) Countries should ensure that the other categories of designated nonfinancial businesses and professions are subject to effective systems for monitoring and ensuring their compliance with requirements to AML/CFT. This should be performed on a risk-sensitive basis. This may be performed by a government authority or by an appropriate self-regulatory organisation, provided that such an organisation can ensure that its members comply with their obligations to AML/CFT.

\section{Recommendation 25}

The competent authorities should establish guidelines, and provide feedback which will assist financial institutions and designated non-financial businesses and professions in applying national measures to AML/CFT, and in particular, in detecting and reporting suspicious transactions. 


\section{NEW FATF RECOMMENDATION RELATED TO DNFBPS}

As a comparison, new recommendation was introduced in 2012 by FATF. There are only two recommendations that are related to DFNBPs which are Recommendation 22 and 23.

Under Recommendation 22, the customer due diligence and record-keeping requirements set out in Recommendations $10,11,12,15$, and 17 , apply to designated non-financial businesses and professions (DNFBPs) in the situations as listed under the recommendation.

There are no significant changes in term of requirements set out in the new recommendation as compared to the previous recommendation relating to DNFBPs. However, FATF has simplified all the recommendations related to DNFBPs into only two recommendations as compared to the previous recommendation.

\section{A. Analysis and Findings}

For the purpose of this study, 5 countries have been chosen randomly to analyze the level of compliance especially in relation to recommendation related to DNFBPs. 5 of the countries including Canada, France, Spain, Mexico and Sweden [6]-[11].

TABLE I: LEVEL OF COMPLIANCE RELATED TO DNFBPS

\begin{tabular}{|c|l|c|c|c|c|c|c|}
\hline & Country & Membership & Last MER & Rec. 12 & Rec. 16 & Rec. 24 & Rec. 25 \\
\hline 1. & Canada & FATF & 2008 & NC & NC & NC & LC \\
\hline 2. & France & FATF & 2011 & PC & PC & NC & PC \\
\hline 3. & Spain & FATF & 2006 & PC & PC & NC & PC \\
\hline 4. & Mexico & FATF & 2008 & NC & NC & NC & LC \\
\hline 5. & Sweden & FATF & 2006 & PC & PC & NC & LC \\
\hline
\end{tabular}

The summary of the analysis is as per Table I. From the table, it can be seen that almost all the countries chosen are still not complying with the recommendations and this also including most of the FATF members that being chosen.

Those statistical, provide clear picture on the reason of the effectiveness in providing the recommendations of DNFBPs for the purpose AML and CFT.

Each recommendation is rated on four point scales as below:

- Compliant $(C)$ - The recommendation is fully observed with respect to all essential criteria.

- Largely Compliant (LC) - There are only minor shortcomings, with a large majority of the essential criteria being fully met.

- Partially Compliant (PC) - The country has taken some substantiate action and complies with some of essential criteria.

- Non-Compliant (NC)- There are major shortcomings, with a large majority of the essential criteria not being met.

The Effective of anti-money laundering and combating the financing of terrorism regimes are essential to protect the integrity of markets and of the global financial framework as they help mitigate the factors that facilitate financial abuse (Min Zhu, Deputy Managing Director of IMF).

For Recommendation 12, 2 countries (Canada and Mexico) did not comply.Some of the factors were that there was no requirement for $\mathrm{CDD}, \mathrm{CDD}$ only apply on some of the businesses and professions or application of CDD implemented but untested. France, Spain and Sweden partially complied with several recommendations being implemented with deficiencies in its implementation.

For Recommendation 16, 2 countries (Canada and Mexico) did not comply. Some of the factors were that there was no requirement for STR or STR only applies on some of the businesses and professions. France, Spain and Sweden partially complied in which they do have STR but the level of reporting implemented was low.

For Recommendation 24, all 5 countries did not comply. There were no regulations or supervisions at all in some of the countries and in some of them, the regulations or supervision only apply on some of the businesses/professions.

For Recommendation 25, Canada, Mexico and Sweden [2], [3], [5], [7] fully complied. France and Spain partially complied as there were no framework and guidelines from the competent authorities. The results of this comparison is true as the result from previous study that stated DNFBPs which were made subject to the standard only in 2003, have had some of the lowest compliances scores.

\section{B. Discussion}

All requirements for financial institutions or DNFBPs should be introduced either (a) in law (see the specific requirements in Recommendations 10, 11 and 20 in this regard), or (b) for all other cases, in law or enforceable means (the country has discretion).

In Recommendations 10, 11 and 20, the term "law" refers to any legislation issued or approved through a Parliamentary process or other equivalent means provided for under the country's constitutional framework, which imposes mandatory requirements with sanctions for non-compliance. The sanctions for non-compliance should be effective, proportionate and dissuasive (see Recommendation 35). The notion of law also encompasses judicial decisions that impose relevant requirements, and which are binding and authoritative in all parts of the country.

The term "Enforceable means" refers to regulations, guidelines, instructions or other documents or mechanisms that set out enforceable AML/CFT requirements in mandatory language with sanctions for non-compliance, and which are issued or approved by a competent authority. The sanctions for non-compliance should be effective, proportionate and dissuasive [12]. In considering whether a document or mechanism has requirements that amount to enforceable means, the following factors should be taken into account:

1) There must be a document or mechanism that sets out or underpins requirements addressing the issues in the FATF Recommendations, and providing clearly stated requirements which are understood as such. For example:

- If particular measures use the word shall or must, this should be considered mandatory;

- If they use should, this could be mandatory if both the regulator and the regulated institutions demonstrate that the actions are directly or indirectly required and are 
being implemented; language such as measures are encouraged, are recommended or institutions should consider is less likely to be regarded as mandatory. In any case where weaker language is used, there is a presumption that the language is not mandatory (unless the country can demonstrate otherwise).

- The document/mechanism must be issued or approved by a competent authority.

2) There must be sanctions for non-compliance (sanctions need not be in the same document that imposes or underpins the requirement, and can be in another document, provided that there are clear links between the requirement and the available sanctions), which should be effective, proportionate and dissuasive. This involves consideration of the following issues:

- There should be an adequate range of effective, proportionate and dissuasive sanctions available if persons fail to comply with their obligations;

- The sanctions should be directly or indirectly applicable for a failure to comply with an AML/CFT requirement. If non-compliance with an AML/CFT requirement does not have a sanction directly attached to it, then the use of sanctions for violation of broader requirements, such as not having proper systems and controls or not operating in a safe and sound manner, is satisfactory provided that, at a minimum, a failure to meet one or more AML/CFT requirements could be (and has been as appropriate) adequately sanctioned without a need to prove additional prudential failures unrelated to AML/CFT; and

- Whether there is satisfactory evidence that effective, proportionate and dissuasive sanctions have been applied in practice.

In all cases it should be apparent that financial institutions and DNFBPs understand that sanctions would be applied for non-compliance and what those sanctions could be.

\section{Recommendation}

Countries should identify, assess, and understand the money laundering and terrorist financing risks for the country, and should take action, including designating an authority or mechanism to coordinate actions to assess risks, and apply resources, aimed at ensuring the risks are mitigated effectively. Based on that assessment, countries should apply a risk-based approach (RBA) to ensure that measures to prevent or mitigate money laundering and terrorist financing are commensurate with the risks identified [13].

This approach should be an essential foundation to efficient allocation of resources across the anti-money laundering and countering the financing of terrorism (AML/CFT) regime and the implementation of risk based measures throughout the FATF Recommendations. Where countries identify higher risks, they should ensure that their AML/CFT regime adequately addresses such risks. Where countries identify lower risks, they may decide to allow simplified measures for some of the FATF Recommendations under certain conditions.

Countries should require financial institutions and designated non-financial businesses and professions (DNFBPs) to identify, assess and take effective action to mitigate their money laundering and terrorist financing risks.

Countries should have national AML/CFT policies, informed by the risks identified, which should be regularly reviewed, and should designate an authority or have a coordination or other mechanism that is responsible for such policies.

Countries should ensure that policy-makers, the financial intelligence unit (FIU), law enforcement authorities, supervisors and other relevant competent authorities, at the policymaking and operational levels, have effective mechanisms in place which enable them to cooperate, and, where appropriate, coordinate domestically with each other concerning the development and implementation of policies and activities to combat money laundering, terrorist financing and the financing of proliferation of weapons of mass destruction.

Countries should criminalize money laundering on the basis of the Vienna Convention and the Palermo Convention. Countries should apply the crime of money laundering to all serious offences, with a view to including the widest range of predicate offences.

Countries should criminalize terrorist financing on the basis of the Terrorist Financing Convention, and should criminalize not only the financing of terrorist acts but also the financing of terrorist organizations and individual terrorists even in the absence of a link to a specific terrorist act or acts. Countries should ensure that such offences are designated as money laundering predicate offences.

Countries should ensure that financial institution secrecy laws do not inhibit implementation of the FATF Recommendations.

Financial institutions should be required to implement programmes against money laundering and terrorist financing. Financial groups should be required to implement group wide programmes against money laundering and terrorist financing, including policies and procedures for sharing information within the group for AML/CFT purposes.

Financial institutions should be required to ensure that their foreign branches and majority owned subsidiaries apply AML/CFT measures consistent with the home country requirements implementing the FATF Recommendations through the financial groups' programmes against money laundering and terrorist financing.

Financial institutions should be required to apply enhanced due diligence measures to business relationships and transactions with natural and legal persons, and financial institutions, from countries for which this is called for by the FATF. The type of enhanced due diligence measures applied should be effective and proportionate to the risks.

Countries should be able to apply appropriate countermeasures when called upon to do so by the FATF. Countries should also be able to apply countermeasures independently of any call by the FATF to do so. Such countermeasures should be effective and proportionate to the risks.

Countries should take measures to prevent the misuse of legal persons for money laundering or terrorist financing. Countries should ensure that there is adequate, accurate and timely information on the beneficial ownership and control of legal persons that can be obtained or accessed in a timely fashion by competent authorities. In particular, countries that have legal persons that are able to issue bearer shares or 
bearer share warrants, or which allow nominee shareholders or nominee directors, should take effective measures to ensure that they are not misused for money laundering or terrorist financing [13].

Countries should consider measures to facilitate access to beneficial ownership and control information by financial institutions and DNFBPs undertaking the requirements set out in Recommendations 10 and 22.

Countries should take measures to prevent the misuse of legal arrangements for money laundering or terrorist financing. In particular, countries should ensure that there is adequate, accurate and timely information on express trusts, including information on the settlor, trustee and beneficiaries that can be obtained or accessed in a timely fashion by competent authorities. Countries should consider measures to facilitate access to beneficial ownership and control information by financial institutions and DNFBPs undertaking the requirements set out in Recommendations 10 and 22 .

\section{CONCLUSION}

There were still major concerned as related to the level of compliance among countries chosen especially on DNFBPs. Several factors as discussed were the reason for this low rate of compliance. Several proposed recommendation were also discussed in this articles. With implementation of the new 40 Recommendation by FATF, there is a high hope that the level of compliance among countries will be better as money laundering is a major global concern since it is a crime without border.

\section{REFERENCES}

[1] AUSTRAC, Typologies and Case Studies Report, 2009

[2] International Standards on Combating Money Laundering and the Financing of Terrorism and Proliferation (The FATF Recommendation), Feb. 2012.
[3] FATF/OECD, "FATF 40 Recommendations," FATF Standards, Financial Action Task Force, 2010.

[4] FATF, "International standards on combating money laundering and the financing of terrorism \& proliferation," FATF Recommendations, Financial Action Task Force, 2012.

[5] Canada's Anti-Money Laundering and Anti-Terrorist Financing Requirement: A Guide for Chartered Accountants, June 2008.

[6] FATF/IMF, Third Mutual Evaluation on Anti-Money Laundering and Combating the Financing of Terrorism, Canada 2008.

[7] FATF/IMF, Third Mutual Evaluation on Anti-Money Laundering and Combating the Financing of Terrorism, Mexico 2008

[8] FATF/IMF, Third Mutual Evaluation on Anti-Money Laundering and Combating the Financing of Terrorism, Spain 2006

[9] FATF/IMF, Third Mutual Evaluation on Anti-Money Laundering and Combating the Financing of Terrorism, Sweden 2006.

[10] N. Jensen and C. A. Png, "Implementation of the FATF 40+9 recommendations," Journal of Money Laundering Control, vol. 14, no. 2, pp. 110-120, 2010.

[11] J. Madinger, Money Laundering: A Guide for Criminal Investigators, $2^{\text {nd }}$ Edition, CRC Press, FL, USA, 2006.

[12] H. Thansegaran and B. Shanmugam, "International trade-based money laundering: The Malaysian perspective," Journal of Money Laundering Control, vol. 10, no. 4, pp. 429-437, 2007.

[13] C. V. Yepes, "Compliance with the AML/CFT International Standard: Lessons from a Cross-Country Analysis," IMF Working Paper, International Monetary Fund, 2011.

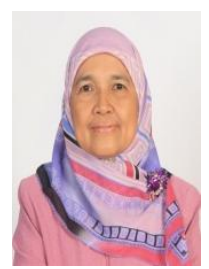

Normah Omar is the director of the Accounting Research Institute (ARI), a Higher Institution Centre of Excellence (HICoE) which is recognized and funded by the Ministry of Higher Education, Malaysia. Prof Normah's research interest is in the area of forensic accounting and financial criminology. As a proponent of applied research, Prof Normah has completed a lot of collaborative research works with government agencies, professional bodies, regulators, non-government organizations and the corporate sectors in Malaysia.

To mention a few, she has successfully completed research projects such as Corporate Governance Rating; The Development of Financial Fraud Red Flags and the Governance of Non Profit Organizations (NPO) within the AML-CFT Regime. Currently Prof Normah is heading one of the Malaysian Institute of Integrity's (MII) collaborative research projects on Corporate Integrity System. To date, Prof Normah sits as editors of seven international refereed journals. She is also the vice president and founding committee member of the Asia-Pacific Management Accounting Association (APMAA) which is based in Japan. 